\title{
EFFECT OF MALTOSE CONCENTRATION IN TRIS DILUTION ON EPIDIDYMAL SPERMATOZOA QUALITY OF BALI BULL PRESERVED AT 5
}

\author{
J. Wattimena, F. Parera dan M. Veerman \\ Department of Animal Science, Agriculture Faculty, Pattimura University \\ Jl. Ir. M. Putuhena Kampus Poka-Ambon 97233 - Indonesia \\ Corresponding Email: jeffriewm@yahoo.com
}

Received August 13, 2009; Accepted November 3, 2009

\begin{abstract}
The objective of research was to evaluate the effect of maltose concentration in Tris dilution on epididymal spermatozoa quality of Bali bull that preserved at $5^{\circ} \mathrm{C}$. Five testis of Bali bull collected from slaughter house were used in this study. Epididymal spermatozoa were collected through slicing and flushing methods, pressing cauda epididymal was conducted in $\mathrm{NaCl}$ physiology ( $\mathrm{NaCl} 0.9 \%$ ) emulsion. Spermatozoa which collected were divided into three reaction tube and each diluted by Tris dilution containing: Tris dilution $+20 \%$ of yolk (control); Tris dilution $+20 \%$ of yolk $+0.3 \mathrm{~g}$ of maltose $/ 100 \mathrm{ml}$ (M0.3); and Tris dilution $+20 \%$ of yolk $+0.6 \mathrm{~g}$ maltose $/ 100 \mathrm{ml}$ (M0.6). Spermatozoa qualities observed were motile spermatozoa (MS), live-spermatozoa (LS) and intact-plasma membrane (IPM) that evaluated daily in refrigerator at temperature of $5^{\circ} \mathrm{C}$. Completely Randomized Design with three treatments and five replications was used in this study. Data was analyzed by analysis of variance. Examination on fresh spermatozoa showed that spermatozoa concentration was 11,222.5 million cell $/ \mathrm{ml}$, motile spermatozoa was $75.00 \%$, live-sperm was $86.75 \%$, abnormal spermatozoa was $10.50 \%$, cytoplasmic droplet was $14.00 \%$ and IPM was $86.75 \%$. At the seventh day of preservation, the percentages of MS, LS and IPM in M0.3 were $37.0 \%, 49.2 \%$ and $50.4 \%$, respectively, and M0.6 were $38.05 \% ; 51.8 \%$ and $52.0 \%$, respectively that were significantly higher $(\mathrm{P}<0.05)$ than control $(29.0 \%$; $41.8 \%$ and $42.4 \%$, respectively). It was concluded that maltose added into Tris dilution could lengthen epididymal spermatozoa quality of Bali bull which persevered at $5^{\circ} \mathrm{C}$.
\end{abstract}

Keywords: Maltose, Preservation, Epididymal Spermatozoa, Bali Bull

\section{INTRODUCTION}

Bali bull is one of superior's commodities which should become the development priority since it has several comparatives superior. Productivity improvements of Bali bull can be conducted by various ways and one of them is Artificial Insemination (AI) implementation. One advantage in implementing AI is increasing productivity and cattle-genetic quality. Spermatozoa from ejaculation that collected by artificial vagina was used in AI. Another alternative for $\mathrm{AI}$ is utilizing cauda epididymal spermatozoa. Cauda epididymal spermatozoa is mature spermatozoa, in which they experienced the maturation process at caput and epididymal corpus parts (Toelihere, 1981; Hafez and Hafez, 2000).

According to Rizal (2005), efforts of processing spermatozoa collected from the epididymal either in fresh or frozen semen for various reproduction technologies can be conducted at animal having superior genetic but its semen can not be collected, saving animal plasma-germ because of sudden death, and rare and wild animals. On some animal species, AI and in-vitro fertilization (IVF) by utilizing cauda epididymal spermatozoa was widely conducted with favorable result as: ram (Graham, 1994; Rizal, 2005), bull (Graham, 1994), boar (Kikuchi et al., 1998), stallion (Squires et al., 2000), red deer (Soler et al., 2003) and spotted buffalo (Rizal et al., 2007; Herdis et al., 2008).

White (1993) stated that semen preservation process in low temperature $\left(3-5^{\circ} \mathrm{C}\right.$ and $\left.-196^{\circ} \mathrm{C}\right)$ damaged the cell plasma membrane of spermatozoa. This was because of cold shock effect. To minimize the negative effect, it can be handled by adding certain substance (cryoprotectant) into semen dilution (Kayser et al., 1992), as glycerol (intracellular cryoprotectant) and some sugar variety 
(extracellular cryoprotecant) (Supriatna and Pasaribu, 1992).

Monosaccharide, disaccharide and polysaccharide sugars are energy resources for spermatozoa and could be utilized as extracellular cryoprotecant to protect spermatozoa during frozen process (Rizal et al., 2003). Yildiz et al. (2000) stated that sugar role in dilution liquid was as the energy resource and cryoprotectant during semen frozen. Maltose as disaccharide sugar is expected to preserve spermatozoa quantity and quality that being diluted in yolk-Tris liquid semen dilution. Several kind of sugars that commonly used were : glucose from the ram frozen semen (Molinia et al., 1993), and boar frozen semen (De Los Reyes et al., 2005); Rafinose from Etawa buck frozen semen (Suwarso, 1999); trehalose from the Garut ram frozen semen (Herdis et al, 2005); Sucrose and Trehalose from the bull frozen semen (Woelders et al., 1997); Lactose from the buck frozen semen (Singh et al., 1995); Garut ram diluted semen (Rizal, 2006) and Maltose from the Garut ram frozen semen (Herdis, 2005).

This research was conducted to find out the effect of maltose added in the Tris dilution to preserve caudal epididymal spermatozoa of Bali Bull at $5^{\circ} \mathrm{C}$. It is expected to minimize the damage of spermatozoa during preservation, so it may extend the vitality.

\section{MATERIALS AND METHODS}

\section{Sperm Collection}

Five Bali bull testis included the epididimal (used for replications) were used in this research. Testis was collected when the cow slaughtered at around 12.00 PM from the Cow Slaughterhouse in Ambon. It, then, was taken and carried to the Animal Production Laboratory, Animal Science Department, University of Pattimura. Spermatozoa collection was started at $7.00 \mathrm{AM}$, initially by the separating epididymal from the testis and washed by using $\mathrm{NaCl}$ physiological liquid $(0.9 \% \mathrm{NaCl})$. Spermatozoa were collected by using combination of Slicing, Rinsing and Pressing Technique (rinse-press) in the $\mathrm{NaCl}$ physiological liquid to each tissue of cauda epididymal (Rizal, 2005). Before the "rinse-press" processed in the $\mathrm{NaCl}$ physiological liquid, spermatozoa concentration was counted using erythrocyte pipette.

Collected spermatozoa were divided equally into three reaction tube. Spermatozoa was diluted by different dilution materials according to the treatments: $80 \%$ Tris base dilution $+20 \%$ Yolk (control), 80\% Tris base dilution $+20 \%$ Yolk + $0.3 \mathrm{~g}$ maltose $/ 100 \mathrm{ml}$ dilution (M0.3) and $80 \%$ Tris basic dilution $+20 \%$ yolk $+0.6 \mathrm{~g}$ maltose/100 $\mathrm{ml}$ dilution (M0.6). Tris basic dilution consisted of $3.87 \mathrm{~g}$ Tris (hidroxymethyl) aminomethane, $2.17 \mathrm{~g}$ citrate acid and $1.56 \mathrm{~g}$ fructose diluted by aquabidestillata until $100 \mathrm{ml}$ and then added by penicillin and streptomycin each for $1000 \mathrm{IU} / \mathrm{ml}$ dilution. Spermatozoa were diluted until reaching 15 million spermatozoa motile/ml concentration. Then, test tubes were closed tightly and included into a goblet filled with clean water and preserved in refrigerator at 5 ${ }^{\circ} \mathrm{C}$. Each treatment's quality was evaluated daily for six days.

\section{Evaluation and Data Analysis}

Spermatozoa's quality was evaluated after collection (fresh spermatozoa), that was: spermatozoa concentration, motile spermatozoa percentage, live spermatozoa percentage, abnormal spermatozoa percentage, cytoplasm droplet percentage and intact plasma membrane percentage. Meanwhile, evaluation on diluted (treated) spermatozoa and preserved was: motile spermatozoa percentage, live spermatozoa percentage and intact plasma membrane percentage.

Table 1. The Characteristics of Bali Bull Epididymal Spermatozoa

\begin{tabular}{lc}
\hline \multicolumn{1}{c}{ Variabels } & Means \pm SD \\
\hline Sperm concentration (million/ml) & $11.222,50 \pm 455.21$ \\
Subjective Sperm Motility (\%) & $75.00 \pm 0.00$ \\
Live Sperm (\%) & $86.75 \pm 0.83$ \\
Abnormality Sperm (\%) & $10.50 \pm 1.12$ \\
Cytoplasmic droplet (\%) & $14.00 \pm 0.71$ \\
Intact Plasma Membrane (\%) & $86.75 \pm 1.48$ \\
\hline
\end{tabular}


Motile spermatozoa percentage, percentage of spermatozoa with progressive motion (moving forward) were evaluated subjectively in eight different view fields with light microscope in 400 times magnification (Rasul et al., 2001). Measurement criteria number ranges between 0 and 100 percent with 5 percent scale.

Live spermatozoa percentage was evaluated by 2 percent eosin B color (Toelihere, 1981). Living- and dead-spermatozoa was marked by transparent head, meanwhile dead spermatozoa was marked by red head. As minimum as 200 spermatozoa was evaluated by light microscope with 400 times magnification.

Intact Plasma Membrane (IPM) percentage was evaluated using osmotic resistance test (ORT) method (Revell and Mrode, 1994). Two hundred $\mu \mathrm{l}$ hypo-osmotic liquid was added by $20 \mu \mathrm{l}$ semen and mixed until homogen and then incubated in $37^{\circ} \mathrm{C}$ for 45 minutes. Preparats made were wrapped in thin on object glass and then was evaluated by using light microscope with 400 times magnification towards minimum 200 spermatozoa. Spermatozoa with intact plasma membrane marked by encircling or swollen tail; meanwhile damaged plasma membrane was marked by straight tail. Hypo-osmotic liquid consisted of $0.9 \mathrm{~g}$ fructose $+0.49 \mathrm{~g}$ sodium citrate diluted by aquabidestillata to reach $100 \mathrm{ml}$ volume.

Data was analyzed by variance analysis in the form of completely randomized design with three treatments and five replications. The difference between treatments was tested by least significant difference test (Steel and Torrie, 1993).

\section{RESULTS AND DISCUSSION}

\section{Characteristics of Epididymal Spermatozoa}

Bali bull epididymal fresh semen characteristics data (Table 1) showed that such semen had a good quality and had the prerequisites to be further processed as research sample. Research result showed that the average of motile spermatozoa was $75.00 \%$, abnormal spermatozoa was $10.5 \%$ and intact plasma membrane was $86.75 \%$. Fresh semen with good quality consisted of motile spermatozoa $\geq 70 \%$ (Evans and Maxwell, 1987), abnormal spermatozoa 6-10\% (Delgadillo, 1992) and intact plasma membrane $\geq 60 \%$ (Revell and Mrodw, 1994).

The average of sperm concentration was 11.222,50 million cells $/ \mathrm{ml}$ (range 10.590-11.780 million cells $/ \mathrm{ml}$ ). Such spermatozoa concentration was higher than other research in bull, that was 3.593-4.406 million cells/ml (Suhendra, 2002) and for Ongole crossbreed bull (PO) was 5.053,3 million cells $/ \mathrm{ml}$. Concentration of cauda epididymal spermatozoa concentration in mammals was reported about 10,000-50,000 million cells/ml (Senger, 1999) and approximately 10.445 million cells $/ \mathrm{ml}$ in spotted buffalo (Yulnawati et al., 2008).

Bali bull cauda epididymal live sperm percentage in this research was approximately $86.75 \%$ (range $85.92-87.52 \%$ ). Yulnawati et al. (2008) reported that live spermatozoa percentage

Table 2. Percentages of Motile Sperm, Live Sperm and Intact Plasma Membrane (IPM) of Bali Bull Epididymal Spermatozoa Preserved at $5{ }^{\circ} \mathrm{C}$

\begin{tabular}{|c|c|c|c|c|}
\hline \multirow{2}{*}{$\begin{array}{c}\text { Quality } \\
\text { Variabel of } \\
\text { Spermatozoa }\end{array}$} & \multirow{2}{*}{$\begin{array}{c}\text { Maltose } \\
(\mathrm{g} / 100 \mathrm{ml})\end{array}$} & \multicolumn{3}{|c|}{ Preservation day } \\
\hline & & 2 & 5 & 7 \\
\hline \multirow{3}{*}{$\begin{array}{c}\text { Motile } \\
\text { Sperm }(\%)\end{array}$} & 0 & $75.00 \pm 0.00^{\mathrm{a}} 67.00 \pm 2.74^{\mathrm{a}} 53.00 \pm 4.47^{\mathrm{a}} 47.00 \pm 2.74^{\mathrm{a}}$ & $42.00 \pm 2.73^{\mathrm{a}}$ & $37.00 \pm 2.74^{\mathrm{a}} 29.00 \pm 2.24^{\mathrm{a}}$ \\
\hline & 0.3 & $75.00 \pm 0.00^{\mathrm{a}} 69.00 \pm 2.24^{\mathrm{a}} 59.00 \pm 2.24^{\mathrm{b}} 56.00 \pm 2.24^{\mathrm{b}}$ & $50.00 \pm 0.00^{\mathrm{b}}$ & $44.00 \pm 2.24^{\mathrm{b}} 37.00 \pm 2.74^{\mathrm{b}}$ \\
\hline & 0.6 & $75.00 \pm 0.00^{\mathrm{a}} 69.00 \pm 2.24^{\mathrm{a}} 59.00 \pm 2.24^{\mathrm{b}} 54.00 \pm 2.24^{\mathrm{b}}$ & $50.00 \pm 3.54^{\mathrm{b}}$ & $45.00 \pm 3.54^{\mathrm{b}} 38.00 \pm 2.74^{\mathrm{b}}$ \\
\hline \multirow{3}{*}{$\begin{array}{c}\text { Live Sperm } \\
(\%)\end{array}$} & 0 & $85.80 \pm 1.10^{\mathrm{a}} 78.20 \pm 2.59^{\mathrm{a}} 63.00 \pm 3.54^{\mathrm{a}} 58.00 \pm 1.23^{\mathrm{a}}$ & $50.40 \pm 3.05^{\mathrm{a}}$ & $47.00 \pm 2.92^{\mathrm{a}} 41.80 \pm 1.30^{\mathrm{a}}$ \\
\hline & 0.3 & $86.60 \pm 1.10^{\mathrm{a}} 80.00 \pm 2.00^{\mathrm{b}} 70.20 \pm 1.79^{\mathrm{b}} 66.60 \pm 3.91^{\mathrm{b}}$ & $61.80 \pm 2.38^{\mathrm{b}}$ & $54.80 \pm 2.78^{b} 49.20 \pm 1.64^{b}$ \\
\hline & 0.6 & $86.60 \pm 1.10^{\mathrm{a}} 82.80 \pm 1.79^{\mathrm{b}} 69.80 \pm 2.05^{\mathrm{b}} 66.00 \pm 1.41^{\mathrm{b}}$ & $61.60 \pm 2.30^{\mathrm{b}}$ & $55.00 \pm 3.67^{\mathrm{b}} 51.80 \pm 4.15^{\mathrm{b}}$ \\
\hline \multirow[t]{3}{*}{ IPM $(\%)$} & 0 & $86.40 \pm 0.89^{\mathrm{a}} 77.80 \pm 1.64^{\mathrm{a}} 69.60 \pm 0.89^{\mathrm{a}} 61.20 \pm 1.64^{\mathrm{a}}$ & $58.40 \pm 3.51^{\mathrm{a}}$ & $49.60 \pm 2.07^{\mathrm{a}} 42.40 \pm 2.07^{\mathrm{a}}$ \\
\hline & 0.3 & $85.60 \pm 0.89^{\mathrm{a}} 80.00 \pm 1.00^{\mathrm{b}} 73.40 \pm 1.14^{\mathrm{b}} 68.00 \pm 1.58^{\mathrm{b}}$ & $65.40 \pm 1.14^{\mathrm{b}}$ & $56.40 \pm 1.67^{\mathrm{b}} 50.40 \pm 1.14^{\mathrm{b}}$ \\
\hline & 0.6 & $85.60 \pm 0.89^{\mathrm{a}} 80.40 \pm 1.14^{\mathrm{b}} 73.00 \pm 0.71^{\mathrm{b}} 68.60 \pm 1.14^{\mathrm{b}}$ & $66.60 \pm 2.30^{\mathrm{b}}$ & $55.40 \pm 2.41^{\mathrm{b}} 52.00 \pm 2.24^{\mathrm{b}}$ \\
\hline
\end{tabular}

a,b Superscrips in a column indicating significant differences $(\mathrm{P}<0,05)$. 
in spotted buffalo cauda epididymis was approximately $79.30 \%$.

The abnormal spermatozoa percentage from this research was approximately $10.50 \%$ (range 9.38-11.62\%) and cytoplasmic droplet percentage was approximately $14.00 \%$ (range 13.29-14.71\%). Abnormal spermatozoa percentage from spotted buffalo was approximately $15.00 \%$ (Yulnawati et al., 2008). Abnormality in spermatozoa from Bali bull cauda epididymal in this research was in the normal range and those can be used for the next process, because according to Bearden and Fuquay (2000) that $8-10 \%$ abnormal spermatozoa has no significant effect on fertility.

Research result showed that the average percentage intact plasma membrane was $86.75 \%$ (Range 85.27-88.23\%). Previously, researcher reported that lower intact plasma membrane percentage in spotted buffalo cauda epididymal spermatozoa was in the average of $80.80 \%$ (Yulnawati et al., 2008). Fresh semen with good quality consisted of intact plasma membrane $\geq$ 60\% (Revell and Mrode, 1994).

\section{Quality of Spermatozoa after Preservation at $5^{\circ} \mathrm{C}$}

\section{The Percentage of Motility Spermatozoa}

The result showed that $0.3 \mathrm{~g}$ maltose addition and $0.6 \mathrm{~g} / 100 \mathrm{ml}$ Tris dilution produced higher real motile spermatozoa percentage than control treatment started from day 2 to the day 7 preservation (Table 2). This showed that maltose was able to give protection and at one time as the energy source substrate for spermatozoa during preservation. High motility in maltose treatment than control was caused by maltose as a disaccharide sugar that can be functioned as energy source. Spermatozoa motility is highly depends on the available energy source in dilute or semen plasma in the form of adenosine triphosphate (ATP) produced from metabolism. According to Gardner and Hafez (1997), the energy required for motility was apparently derived from extracellular stores of ATP. The use of ATP appears to be regulated by the endogenous level of cyclic adenosine monophosphate (cAMP). The cAMP not only regulates ATP breakdown but also has a direct effect on sperm motility. Brandt and Hoskins (1980), stated that cAMP was involved in the regulation of spermatozoa motility. Elevation of intracellular cAMP level appears to be related: to the acquisition of the potential for motility during epididymal maturation, to the actual initiation of motility upon ejaculation and to the surge of increased motility associated with capacitation. Woelders et al. (1997) demonstrated that an isotonic sugar medium in which Tris-citrate components were substituted by sucrose (disaccharide) and trehalose was significantly superior to a Tris-citrate egg yolk medium in preserving the motility and acrosome integrity of bovine spermatozoa.

Maltose as disaccharide sugar can be used as energy source through glycolysis process. Before glycolysis, disaccharide will be hydrolyzed by disaccharidase enzyme (Salisbury and Van demark, 1985). Maltase enzyme will break maltose into two glucose molecules. Spermatozoa will be easier to use glucose in its metabolism than other energy source use available in semen plasma that was fructose (Toelihere, 1993). According to Hammerstedt (1993), spermatozoa viability very depend on energy source which was found in semen plasma or dilution and could not be self syntheses energy that needed to metabolism and repair cell's damage. Protein in egg yolk takes part in support spermatozoa motility, because the protein was able to protect spermatozoa plasma membrane, in order to well functioned the cell organelle, included the metabolism process.

\section{The Percentage of Live Spermatozoa}

Salisbury and Van Demark (1985) suggested that viability spermatozoa was the spermatozoa's ability to active stationery after incubation in higher temperature from room temperature or after being kept in the lower temperature. The result of this research showed that the addition of maltose $0.3 \mathrm{~g} / 100 \mathrm{ml}$ and $0.6 \mathrm{~g} / 100 \mathrm{ml}$ Tris dilution provided presentation of live spermatozoa until 6 days preservation (during 5 days) were significant $(\mathrm{P}<0.05)$ than control. It indicated that the existence of maltose in Tris dilution provided energy source for spermatozoa so that their viability more than 5 days (Table 2), but according to Evans and Maxwell (1987) and Indonesia National Standard (SNI) about semen quality requirement used in AI programme must have minimum percentage of motile spermatozoa that is about $40 \%$. In the control treatment, motile spermatozoa percentage in $40 \%$ can be defensible only until 5 days preservation (during 4 days), whereas by the adding of maltose $(0.3 \mathrm{~g}$ and 0.6 g) can be defensible until 6 days preservation 
(during 5 days). Spermatozoa that were kept in room temperature $\left(37^{\circ} \mathrm{C}\right)$ have only several hour viability because of nutrition run out. Toelihere (1981) stated that the increasing of $\mathrm{pH}$ because of lactate acid accumulation and alteration which is occurred because spermatozoa's affected on spermatozoa's viability. Spermatozoa's viability in vitro was affected by essence contained in dilution and spermatozoa's quality. Good quality of spermatozoa had ability to outlive, because of having bigger ability to absorb nutrition (Gilbert, 1988; King, 1993). Spermatozoa with good quality completed plasmalemma and acrosoma, so they were able to absorb nutrition essence which were secreted by sertoli cell, whereas the high plasmalemma permeability needed to live on from $\mathrm{pH}$ alteration and osmosis pressured alteration (Lamming, 1990).

Membrane integrity was the vital importance for sperm viability. Pursel et al. (2009) reported that the results of five extenders used consisted of Tris $(0.164 \mathrm{M})$ and citric acid $(0.055 \mathrm{M})$ in combination with glucose, fructose, lactose, sucrose or raffinose $(0.138 \mathrm{M})$ indicated that the sugar composition of the extender may effect the development of cold shock resistance during incubation. The sugar composition of semen extenders has previously been shown to be a significant factor during freezing of bull and ram spermatozoa (Salamon and Lightfoot, 1969).

\section{The Percentage of Intact Plasma Membrane (IPM)}

Maltose is extracellular cryoprotectant to protect spermatozoa's plasma membrane from damage caused by the cold shock effect during storage in $5^{\circ} \mathrm{C}$. That was apparently from research result whereas intact plasma membrane percentage in real maltose treatment $(0.3 \mathrm{~g} / 100 \mathrm{ml}$ and $0.6 \mathrm{~g} / 100 \mathrm{ml})$ were significant $(\mathrm{P}<0.05)$ higher than control started from two days until 7 days of preservation (Table 2). Several researchers found that the incorporation of sugars in sperm diluents protects the spermatozoa of many species against freeze damage. Sugars probably play a key role in preventing deleterious alteration to the membrane during reduced-water states (Aimen et al., 2003). Pursel et al. (1972) stated that sugar and addition of egg yolk had a significant effect on cold shock resistance. According to White (1993), the influence of cold shock related to phospholipids alteration cell plasma membrane compiler, that the transformation was from liquid to gel which was occurred under $20^{\circ} \mathrm{C}$ temperature. The alteration of fat acid and protein in plasma membrane caused leakage or plasma membrane selectivity damaged that influence of ions entered cell openly. Supriatna and Pasaribu (1992) stated that carbohydrate was extracellular cryoprotectant which functioned to protect the cell plasma membrane from damage. Whole-cell plasma membrane passed to the positive effect of motility and viability spermatozoa. Spermatozoa's motility depends to energy supply of ATP from result metabolism. Metabolism will work out well if cell plasma membrane still complete. Because cell plasma membrane take part in arrange traffic substrate and electrolyte's entry and exit that needed in metabolism process in cell (Lehninger, 1994).

Cell plasma membrane contain carbohydrate which is alliance with lipid (glicolipid) or protein (glicoprotein) which is called cell cover or glicokalics (Lehninger, 1994). Carbohydrate is also known as extracellular cryoprotectant because estimated functioned in protection of glicokalics spermatozoa's cell plasma membrane from damage process during semen preservation. According to Viswanath and Shannon (2000) cryoprotectant composite carbohydrate category, like maltose have ability to change water molecule normally in hydrated polar class. The characteristics of maltose will help stabilize spermatozoa's cell plasma membrane during transition through the critic temperature zone, and change the character of dilution mechanic through viscosities. Aisen et al. (2002) reported that disaccharide carbohydrate categories act as water substitute on the surface of cell plasma membrane which direct related with dilution. Furthermore, they stated that maltose was able to interact with polar phospholipids center cluster during solidification and reduce bond interact Van der Walls between carbon chain.

Sugar contribute to stability of the membranes, as it has been found in a number of other cells dehydrated during freeze drying or low-rate freezing and thawing (Eiman et al., 2003). The presence of sugars in the diluents is likely to affect the pattern of crystallization and the shape and width of the channels of unfrozen solution (Nicollajsen and Hvidt, 1994), which could perhaps relieve or prevent fast-cooling damage to the spermatozoa. The presence of sugars leads to a lower salt concentration in the unfrozen water, consequently reducing the effects of the solution. It is possible that the sugars may 
help prevent injurious eutectic freezing by trapping salts in an increasingly viscous or even glass-like phase. Giraud et al. (2000) reported that the recovery rate of viable or motile spermatozoa after freezing or thawing is superior for spermatozoa with high membrane fluidity before freezing.

\section{CONCLUSION}

The percentage of motile spermatozoa, live spermatozoa and intact plasma membrane in the $7^{\text {th }}$ day of preservation were about $29.00 \%$, $41.80 \%$ and $42.40 \%$ for treatment of $0.0 \mathrm{~g}$ maltose; $37.00 \%, \quad 49.20 \%$ and $50.40 \%$ for treatment of $0.3 \mathrm{~g}$ maltose; $38.00 \%, 51.80 \%$ and $52.00 \%$ for treatment of $0.6 \mathrm{~g}$ maltose. Addition $0.3 \mathrm{~g}$ and $0.6 \mathrm{~g} / 100 \mathrm{ml}$ maltose in Tris dilution able to extending Bali bull epididymal spermatozoa quality which was preserved in $5^{\circ} \mathrm{C}$ temperature and qualified to benefit the $\mathrm{AI}$ program after the $5^{\text {th }}$ day of preservation, whereas without added maltose can only preserve for 4 days.

\section{REFFERENCES}

Aisen, E.G., V.H. Medina and A. Venturino. 2002. Cryopreservation and post-thawed fertility of ram frozen semen in different trehalose concentrations. Theriogenology 57: 1801-1808.

Eiman, M., E. Aboagla and T. Terada. 2003. Trehalose-enhanced fluidity of goat sperm membrane and its pratectin during freezing. Biology Reproduction 69: 1245-1250.

Bearden, H.J. and J.W. Fuquay. 2000. Applied Animal Reproduction fifth Edition. Prentice Hall, Upper Saddle, New Jersey.

Brandt, H. and D.D. Hoskins. 1980. A cAMPdependent phosphorylated motility protein in bovine epididymal sperm. J. Biological Chemistry 255 (10): 982-987.

De Los Reyes, M., L. Saenz, L. Lapiere, J. Crosby and C. Barros. 2000. In vitro evaluation of boar spermatozoa frozen with permeable and non-permeable cryoprotectant. Proceeding of $14^{\text {th }}$ International Congress on Animal Reproduction. Stockholm, 2-6 July 2000. ICAR. Stockholm, Sweden. Abstracts Vol. 2. p. 161.

Evans, G. and W.M.C. Maxwell. 1987. Salamon's Artificial Insemination of Sheep and Goats. Butterworths, London.
Gardner, D.L. and E.S.E. Hafez. 1997. Spermatozoa and Seminal Plasma. In Hafez, E.S.E. Reproduction in Farm Animals $6^{\text {th }}$ Edition. Lea and Febiger. Philadelphia.

Gilbert, S.F. 1988. Developmental Biology. Second Edition; Sinauer Associates, Inc. Publishers. Massachusetts.

Giraud, M.N., C. Motte, D. Boucher and G. Grizard. 2000. Membrane fluidity predicts the outcome of cryopreservation of human spermatozoa. Hum. Reprod. 15:2160-2164.

Graham, J.K. 1994. Effect of seminal plasma on the motility of epididymal and ejaculated sperma-tozoa of the ram and bull during cryoprservation process. Theriogenology 46: 1151-1162.

Hafez, E.S.E. and B. Hafez. 2000. Reproduction in Farm Animals $7^{\text {th }}$ Edition. Lippincott Williams and Wilkins, Baltimore.

Herdis. 2005. Optimalisasi Inseminasi Buatan melalui Aplikasi Teknologi Laserpunktur pada Domba Garut (ovis aries). Disertasi. Institut Pertanian Bogor, Bogor.

Herdis, M. Rizal, A. Boediono, R.I. Arifiantini T. Saili, A.S. Aku, dan Yulnawati. 2005. Optimasi kualitas semen beku domba garut melalui penambahan trehalosa ke dalam pengencer kuning telur. J. Pengembangan Peternakan Tropis 30: 229-236.

Herdis, M. Surachman, Yulnawati, M. Rizal dan H. Maheshwari. 2008. Viabilitas dan keutuhan membran plasma spermatozoa epididimis kerbau belang pada penambahan maltosa dalam pengencer AndroMed ${ }^{\circledR}$. J. Pengembangan Peternakan Tropis. 33:101106.

Jildiz, C., A. Kaya, M. Asoy and T. Tekeli. 2000. Influence of sugar supplementation of the extender on motility, viability and acrosomal integrity of dog spermatozoa during freezing. Theriogenology. 54:579585.

Kayser, J.P., R.P. Amann, R.K. Shidefer, E.L. Squires, D.J. Jasko and B.W. Pickett. 1992. Effects of liniar cooling rate on motion characteristics of stallion spermatozoa. Theriogenology 30: 601-614.

Kikuchi, K., T. Nagai, N. Kashiwazaki, H. Ikeda, J. Noguchi, A. Shimada, E. Soloy and H. Kaneko. 1998. Cryopreservation and ensuing in vitro fertilization ability of boar spermatozoa from epididymides stored at $4^{\circ} \mathrm{C}$. Theriogenology 50: 615-623.

King, C.J. 1993. Reproduction in Domesticated 
Animals. Elservier Science Pub. New York.

Lamming, G.E. 1990. Marshall's Physiology of Reproduction. Reproduction in the Animal. Churchil Livingstone. New York. Vol. 2.

Lehninger, A.L. 1994. Dasar-dasar Biokimia Jilid 2. Alih bahasa: M. Thenawijaya. Erlangga, Jakarta.

Molinia, F.C., G. Evans, P.I. GuintanaCasares,and W.M.C. Maxwell. 1993. Effect of mono-saccharides in Tris-based diluents on motility, acrosomes integrity and fertility of pellet frozen ram spermatozoa. Anim. Reprod. Sci. 36: 113-122.

Nicollajsen, $\mathrm{H}$ and H. Hvidt. 1994. A phase behaviour of the System trehalose-NaClwater. Cryobiology 31: 199-205

Pursel, V.G., L.A. Johnson and L.L. Schulman. 1972. Interaction of extender composition and incubation on cold shock susceptibility of boar sperm. J. Anim. Sci. 35: 580-584.

Rasul, Z., N. Ahmad, dan M. Anzar. 2001. Changes in motion characteristics, plasma membrane integrity and acrosome morphology during cryopreservation of buffalo spermatozoa. J. Androl. 22:278-283.

Revell, S.G. and R.A. Mrode. 1994. An osmotic resistance test for bovine semen. Anim. Reprod. Sci. 36:77-86.

Rizal, M., M.R. Toelihere, T.L. Yusuf, B. Purwantara dan P. Situmorang. 2003. Kriopreservasi semen domba garut dalam pengencer tris dengan konsentrasi laktosa yang berbeda. JITV 11: 123-130.

Rizal, M. 2005. Fertilitas spermatozoa ejakulat dan epididimis domba garut hasil kriopreservasi menggunakan modifikasi pengencer tris dengan berbagai krioprotektan dan antioksidan. Disertasi, Institut Pertanian Bogor, Bogor.

Rizal, M. 2006. Pengaruh penambahan laktosa di dalam pengencer Tris terhadap kualitas semen cair domba Garut. J. Pengembangan Peternakan Tropis 31: 224-231.

Rizal, M., Herdis, Yulnawati, dan H. Maheshwari. 2007. Peningkatan kualitas spermatozoa epididimis kerbau belang yang dikriopreservasi dengan beberapa konsentrasi sukrosa. J. Veteriner 8:188-193.

Salamon, S and R.J. Lightfoot. 1969. Freezing Ram Spermatozoa by the Pellet Method. I. The effect of diluent composition on survival of spermatozoa. Australian J. Biol. Sci. 22: 1527.

Salisbury, G.W. and N.L. Van De Mark. 1985.
Physiology of Reproduction and Artificial Insemination of Cattle. Freeman and Company. London

Senger, P.L. 1999. Pathways to Pregnancy and Parturition. Current Conception Inc., Pullman.

Singh, M.P., A.K. Sinha, and B.K. Singh. 1995. Effect of cryoprotectants on certain seminal attributes and on the fertility of buck spermatozoa. Theriogenology 43: 10471053.

Soler, A.J., M.D. Perez-Gusman, and J.J. Garde. 2003. Storage of red deer epididymides for four days at $5^{\circ} \mathrm{C}$ : effects on sperm motility, viability, and morphology integrity. J. Exp. Zool. 295A: 188-199.

Steel, R.G.D. dan J.H. Torrie. 1993. Principles and Procedures of Statistics. McGraw-Hill Book Company Inc. New York.

Supriatna, I. dan F.H. Pasaribu. 1992. In Vitro Fertilisasi, Transfer Embrio, dan Pembekuan Embrio. Pusat Antar Universitas, Institut Pertanian Bogor, Bogor.

Suwarso. 1999. Peranan Rafinosa dalam Pengencer Tris-sitrat-kuning telur terhadap Kualitas Semen Beku Kambing Peranakan Etawah. Tesis. Program Pascasarjana, Institut Pertanian Bogor, Bogor.

Toelihere, M.R. 1981. Inseminasi Buatan pada Ternak. Angkasa, Bandung.

Viswanath, R. and P. Shannon. 2000. Storage of bovine semen in liquid frozen state. Anim. Reprod. Sci. 62: 23-53.

White, I.G. 1993. Lipid and Ca uptake of sperm in relation to cold shock and preservation: A review. Reprod. Fertil. Dev. 5: 639-658.

Woelders, H., A. Matthij and B. Engel. 1997. Effect of trehalose and sucrose, osmolality of the freezing medium, and cooling rate on viability and intactness of bull sperm after freezing and thawing. Cryobiology 35:93105.

Yildiz, C., A. Kaya, M. Aksoy and T. Tekeli. 2000. Influence of sugar supplementation of the extender on motility, viability and acrosome integrity of dog spermatozoa during freezing. Theriogenolory. 54:579585.

Yulnawati, Herdis, H. Maheshwari dan M. Rizal. 2008. Kualitas spermatozoa epididimis kerbau belang pada penambahan raffinosa sebagai krioprotektan ekstraseluler. JITV 13: 30-34. 